\title{
Chemical composition of rainwater at Maldives Climate Observatory at Hanimaadhoo (MCOH)
}

\author{
R. Das ${ }^{1}$, L. Granat ${ }^{1}$, C. Leck ${ }^{1}$, P. S. Praveen ${ }^{2}$, and H. Rodhe ${ }^{1}$ \\ ${ }^{1}$ Department of Meteorology, Stockholm University, 10691 Stockholm, Sweden \\ ${ }^{2}$ Maldives Climate Observatory Hanimaadhoo, The Maldives
}

Received: 15 June 2010 - Published in Atmos. Chem. Phys. Discuss.: 20 July 2010

Revised: 28 February 2011 - Accepted: 23 March 2011 - Published: 26 April 2011

\begin{abstract}
Water-soluble inorganic components in rain deposited at the Maldives Climate Observatory Hanimaadhoo $(\mathrm{MCOH})$ were examined to determine seasonality and possible source regions. The study, which is part of the Atmospheric Brown Cloud (ABC) project, covers the period June 2005 to December 2007. Air mass trajectories were used to separate the data into situations with transport of air from India and adjacent parts of the Asian continent during the months December and January (Indian group) and those with southerly flow from the Indian Ocean during the summer monsoon season June to September (Marine group). A third trajectory group was identified with transport from the northern parts of the Arabian Sea and adjacent land areas during the months March, April and October (Arabian Sea group). The concentrations of nss- $\mathrm{SO}_{4}^{2-}, \mathrm{NH}_{4}^{+}$and $\mathrm{NO}_{3}^{-}$ were more than a factor of 4 higher in the Indian group than in the Marine group. The average rainwater $\mathrm{pH}$ was significantly lower in the Indian group (4.7) than in the Marine group (6.0). This shows a pronounced influence of continental pollutants during December and January. The origin of the very high concentration of nss- $\mathrm{Ca}^{2+}$ found in the Marine group - a factor of 7 higher than in the Indian group - is unclear. We discuss various possibilities including longrange transport from the African or Australian continents, local dust from nearby islands and calcareous plankton debris and exopolymer gels emitted from the ocean surface. The occurrence of $\mathrm{NO}_{3}^{-}$and $\mathrm{NH}_{4}^{+}$in the Marine group suggests emissions from the ocean surface. Part of the $\mathrm{NO}_{3}^{-}$could also be associated with lightning over the ocean. Despite the fact that the concentrations of nss- $\mathrm{SO}_{4}^{2-}, \mathrm{NO}_{3}^{-}$, and $\mathrm{NH}_{4}^{+}$were highest in the Indian group the wet deposition was at least as
\end{abstract}

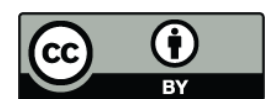

Correspondence to: C. Leck (lina@misu.su.se) big in the Marine group reflecting the larger amount of rainfall during the monsoon season. The annual wet deposition of $\mathrm{NO}_{3}^{-}, \mathrm{NH}_{4}^{+}$and nss- $\mathrm{SO}_{4}^{2-}$ at $\mathrm{MCOH}$ is about a factor of three lower than observed at rural sites in India.

\section{Introduction}

The Indian Ocean Experiment (INDOEX) intense field campaign carried out during January to April 1999 illuminated and described the phenomenon of brown clouds over South Asia and Northern Indian Ocean due to long range transport of anthropogenic aerosol particles during the dry winter monsoon season. During this season the continental pollutants from Northern Hemisphere are transported by a northeasterly flow towards the inter-tropical convergence zone (ITCZ). The brown clouds consist of a mixture of anthropogenic sulfate, nitrate, organics, black carbon, dust, fly ash and natural aerosol particles such as sea salt and mineral dust. The anthropogenic particles contribute about $80 \%$ to the total aerosol load over most of south Asia and northern Indian Ocean (Ramanathan et al., 2001; Guazzotti et al., 2003). The composition of brown clouds has significant implications for radiative forcing of climate, the hydrological cycle, agriculture and health (Ramanathan et al., 2001, 2005, 2007a, b; Guazzotti et al., 2001; Gabriel et al., 2002; Stone et al., 2007; Corrigan et al., 2006, 2008). In response to the findings of INDOEX the international Atmospheric Brown Cloud (ABC) project was designed to address the environmental impact of the brown clouds on regional and global scales. The project specifically aimed at monitoring radiative effects, climate change and atmospheric pollution in the Asia Pacific region (Ramanathan and Crutzen, 2003). One of the key sites for observations related to the brown clouds

Published by Copernicus Publications on behalf of the European Geosciences Union. 
in South Asia is the Maldives Climate Observatory at Hanimadhoo (MCOH) located at $6^{\circ} 46 \mathrm{~N}$ and $73^{\circ} 11 \mathrm{E}$ in the northern part of Hanimadhoo island in the Republic of Maldives (Fig. 1). The island is situated in the upper north-east corner of Maldivian archipelago. The weather is characterized by the dry winter season during November to April and the wet monsoon season during June to October. The north-easterly winds carry polluted air from the Asian continent, including the Middle east, out over the Indian Ocean during winter while the south-easterly winds during the wet monsoon season - turning south-westerly before they reach the continent brings tropical remote marine air that provides India with most of its annual rainfall. The $\mathrm{MCOH}$ therefore serves as an ideal location for sampling air coming either from Asia or from the Southern Hemisphere and it is free from significant local sources of pollution. Further details of the monsoon system and pollution transport are described elsewhere $(\mathrm{Kr}-$ ishnamurti et al., 1998; Verver et al., 2001; Ramachandran, 2005; Momin et al., 2005; Corrigan et al., 2006). Scavenging by precipitation is an important mechanism for removing pollutants from the atmosphere. Measurements of the chemical composition of precipitation are therefore a fundamental prerequisite for estimating the cycling through the atmosphere of components occurring in aerosol particles and as soluble gases. Such measurements also provide information on the input of anthropogenic and natural components to terrestrial, aquatic and marine ecosystems. Precipitation chemistry studies in the South Asian region have been carried out mainly in India (Kulshrestha et al., 1999, 2005; Granat et al., 2002; Mouli et al., 2005; Momin et al., 2005; Tiwari et al., 2007; Rastogi and Sarin, 2007; Salve et al., 2008; Budhavant et al., 2009). No systematic long-term measurements have been carried out previously in the Maldives or at other locations in the northern parts of the Indian Ocean. The present paper describes the chemical composition of rainwater at $\mathrm{MCOH}$ collected during the period June 2005 to December 2007. The aim of the study is to characterize the seasonality of the inorganic components of the rain deposited at $\mathrm{MCOH}$ and to identify possible anthropogenic and natural sources. In a separate paper (Granat et al., 2010) a comparison is made between the chemical composition of rainwater and of aerosol particles collected in air at $\mathrm{MCOH}$. The main emphasis of that paper was on the scavenging characteristics of light absorbing material (soot) compared to other components.

\section{Methods}

\subsection{Sampling}

Precipitation samples were collected during the period June 2005 to December 2007 on a daily basis at 06:00 a.m. sometimes also a second time at 06:00 p.m. (local time) - using two wet-only collectors of MISU (Department of Mete-
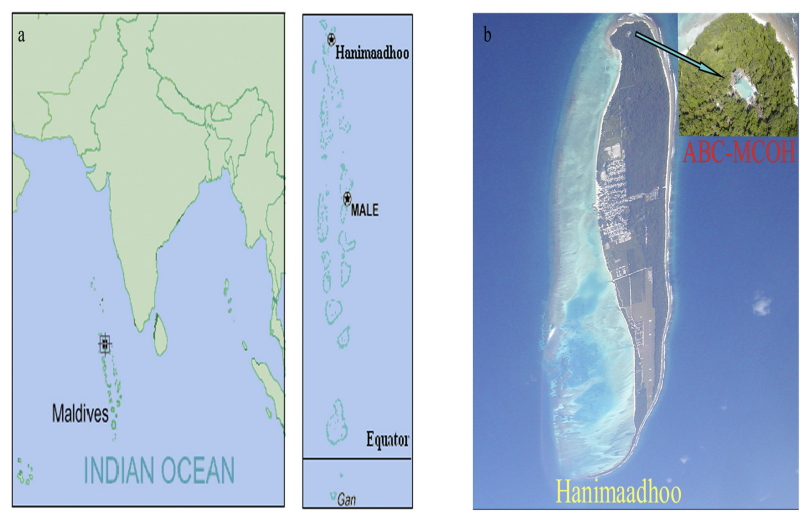

Fig. 1. Location of the Maldives Climate Observatory at Hanimaadhoo $(\mathrm{MCOH})$.

orology, Stockholm University, Sweden) design located outside the railing at the top of a $15 \mathrm{~m}$ tower at $\mathrm{MCOH}$. The collector consists of a cylindrical part with a polyethylene funnel (diameter ca $200 \mathrm{~mm}$ ) and a bottle inside and with a polypropylene lid making a tight seal against the collector. The funnel has a screw cap moulded to the spout to give a watertight connection to the collecting bottle with no possibility for rain to enter from the side of funnel. A second wet-only collector of the same type but with funnel and bottle made of glass (Granat et al., 2010) was used primarily for sampling of soot but also as a quality check on sampling reproducibility for inorganic compounds. Once a week (Monday morning) the funnel was sprayed with de-ionized water (DI), (18 $\mathrm{M} \Omega \mathrm{cm}$ resistivity), and the runoff collected, weighed and treated in the same way as the rain samples (below referred to as w1-first wash). More washing's followed to give a clean funnel with test sample collected. Sample from the DI in the spray bottle was also collected for later analysis. The brush used for cleaning was kept in a plastic bag between events. Plastic gloves were used during collection of rain samples and at funnel washing. The samples were transferred to $50 \mathrm{~cm}^{3}$ polyethylene bottles for shipping and analysis by ion chromatography (IC) at MISU. The amount of each sample collected was determined by weighing on an electronic balance. To prevent biological degradation in the rainwater samples during storage and transport, a preservative was added in advance at MISU to the empty transport bottles (to give $400 \mathrm{mg}$ Thymol per $\mathrm{dm}^{3}$, Gillett and Ayers, 1991). By this procedure any spill of Thymol in the station environment was eliminated. All samples were stored in a refrigerator $\left(4^{\circ} \mathrm{C}\right)$ at the observatory and after arrival at MISU.

\subsection{Analysis of the rain samples}

After filtration the rainwater samples were analyzed for major cations (ammonium: $\mathrm{NH}_{4}^{+}$, sodium: $\mathrm{Na}^{+}$, potassium: $\mathrm{K}^{+}$, magnesium: $\mathrm{Mg}^{2+}$ and calcium: $\mathrm{Ca}^{2+}$ ) and anions 
(fluoride: $\mathrm{F}^{-}$, chloride: $\mathrm{Cl}^{-}$, formate: $\mathrm{HCOO}^{-}$, acetate: $\mathrm{CH}_{3} \mathrm{COO}^{-}$, methane sulfonate, $\mathrm{MSA}: \mathrm{CH}_{3} \mathrm{SO}_{2} \mathrm{O}^{-}$, nitrate: $\mathrm{NO}_{3}^{-}$, bicarbonate: $\mathrm{HCO}_{3}^{-}$, and sulfate: $\mathrm{SO}_{4}^{2-}$ ) by ion chromatography (Dionex ICS-2000). $\mathrm{pH}$ and conductivity was analysed in an unfiltered fraction of each sample. The anions were analyzed with Dionex AG11/AS11columns and an ASRS-II auto suppressor mode, eluent potassium hydroxyl $0.2 \mathrm{mM}$ at $0.5 \mathrm{~cm}^{3} \mathrm{~min}^{-1}$ for weakly retained anions (MSA), gradually increasing to $25 \mathrm{mM}$ to elute strongly retained ions. In samples collected before February 2007 the analysis of cations was made with Dionex CG12A/CS12A columns (column temperature $20^{\circ} \mathrm{C}$ ) and a CSRS-II auto suppressor with external water mode and $18.5 \mathrm{mM}$ MSA eluent (isocratic) with a flow of $0.25 \mathrm{~cm}^{3} \mathrm{~min}^{-1}$. From February 2007 the analyses of cations were made with Dionex CG16/CS16 columns (column temperature $40^{\circ} \mathrm{C}$ ) with $30 \mathrm{mM}$ MSA using an eluent generator with DI water. $\mathrm{pH}$ was measured with Orion model $720 \mathrm{pH}$ meter with combination glass electrode Ross sure flow (model for low ionic strength samples). Conductivity was measured with Orion conductivity meter 120 . All samples collected contained a certain amount of sea salt. To be able to apportion the measured quantities to different sources it is necessary to estimate the non sea salt (nss) concentration of the various components. This was calculated using the observed rain-water concentrations of $\mathrm{Na}^{+}$as the reference element and assuming that all $\mathrm{Na}^{+}$is of marine origin (Keene et al., 1986). The non sea salt concentration of any particular component " $\mathrm{X}$ " is calculated based on the known sea water ratios with respect to $\mathrm{Na}^{+}$:

$[\mathrm{nss}-\mathrm{X}]=\left[\mathrm{X}_{\text {rain }}\right]-\left[\mathrm{Na}_{\text {rain }}^{+}\right]\left\{\mathrm{X} / \mathrm{Na}^{+}\right\}_{\text {seawater }}$

\subsection{Data quality}

Quality control of the analyses was done based on laboratory produced test samples and certified reference samples. Random error, calculated from analyses of a synthetic sample in each batch, and given as one standard deviation, was $10 \%$ for cations and 3\% for anions ( $\mathrm{HCO}_{3}^{-}$was not included). Systematic errors as evaluated by an inter-laboratory test (organized by EANET, 2008) with concentrations similar to the present ones were less than $2 \%$ (with exception for $\mathrm{Mg}^{2+}$ with less than 3\%) for all components, except $\mathrm{HCO}_{3}^{-}$that was not included in the test. The quality of the chemical analyses was also assessed by the ion balance (sum of anions versus sum of cations) and by a comparison between measured and calculated conductivity. The average difference between anions and cations $(\mathrm{A}-\mathrm{C} /(\mathrm{A}+\mathrm{C}))$ was $0.1 \%$, well below the limits recommended by Mohnen et al. (1994) for precipitation chemistry analyses. The standard deviation of the difference was $5 \%$ of the sum of anions and cations while the difference was only below 0.03 in $66 \%$ of the samples. A further check was obtained by an analysis of sea water, collected from the ocean at $\mathrm{MCOH}$ and diluted 5000 times to give a $\mathrm{Na}^{+}$concentration typical for the rainwater samples. Concentration ratios to $\mathrm{Na}^{+}$agreed better than $2 \%$, but was $3 \%$ for $\mathrm{Cl}^{-}$and $5 \%$ for $\mathrm{K}^{+}$to those reported for seawater, thus in line with the precision of the method and relevant for calculating nss-concentrations. Assessment of sampling quality was made by a regular washing program and by comparing chemical analyses from two nearby wet-only collectors. The funnel was washed once a week (Monday morning) and the run-off from the funnel (w1), was weighed and treated in the same way as the rain samples. The median amount (in $\mu$ eq of each component) in this wash water (containing the major part of soluble compounds in the funnel as estimated from succeeding washes) was less than $10 \%$ for all major compounds except nss- $\mathrm{K}^{+}\left(3 \%\right.$ for $\mathrm{NO}_{3}^{-} ; 2 \%$ for nss- $\mathrm{SO}_{4}^{2-} ; 7 \%$ for $\mathrm{Na}^{+} ; \mathrm{Cl}^{-} 9 \%$ for $\mathrm{nss}^{-} \mathrm{Ca}^{2+} ; 10 \%$ for $\mathrm{NH}_{4}^{+} ; 35 \%$ for nss- $\mathrm{K}^{+}$) of the median amount for the same component in collected rain samples. The amount of a component in $\mathrm{w} 1$ can be due to material depositing into the funnel when the lid is accidentally open or improper handling by the operator during collecting the w1 sample. Regardless of source this non-rain component is sufficiently small not to be of any concern. This clearly shows that the high nss- $\mathrm{Ca}^{2+}$ concentrations in marine rains are not due to dust entering the funnel between rain events. Inorganic analyses (from 103 events) obtained from the glass wet-only collector were compared with those from the plastic collector. For sea salt $\mathrm{Na}^{+}$) there was a good agreement between the two collectors, close to the analytical reproducibility, in 87 out of the 101 samples. In 13 samples the $\mathrm{Na}^{+}$concentration was substantially higher in the glass collector while in one case the concentration was higher in the plastic collector. The likely explanation is that the lid opening/closing mechanism failed in some cases for the glass collector and in one for the plastic collector and left the collector open also during dry periods during which sea salt was deposited in the open collector. For nss- $\mathrm{Ca}^{2+}$ the result is similar: 9 cases with much higher concentration in the glass collector and with a fair agreement between the remaining cases. For nss- $\mathrm{SO}_{4}^{2-}$ there was a very good agreement for all samples (slope 0.99 and $r^{2}=0.98$ ). Obviously, the nss- $\mathrm{SO}_{4}^{2-}$, with most of the mass in the fine particle mode (Granat et al., 2010), did not deposit to an appreciable amount during exposed, dry periods. The agreement of $\mathrm{NH}_{4}^{+}$concentrations between collectors was quite poor. This is explained by the uncertainty in determining low concentrations of $\mathrm{NH}_{4}^{+}$in the presence of high concentrations of $\mathrm{Na}^{+}$. The standard deviation of $\mathrm{NH}_{4}^{+}$for individual samples relative to average for a single collector was 0.4. In the case of nss- $\mathrm{K}^{+}$it was even larger (1.1), an obvious effect of analytical uncertainty when random error for the total $\mathrm{K}^{+}$ concentration is related to the much smaller concentration of nss- $\mathrm{K}^{+}$. Tests showed that when the lid opening mechanism was turned off, no detectable amount of any of the components could be found in the funnel even after extended periods. The lid does thus give a tight seal to the collector. 


\subsection{Trajectories}

Daily 10 days receptor-oriented trajectories were calculated for $\mathrm{MCOH}$ using the Hysplit 4.8 model from the National Oceanic and Atmospheric Administration (NOAA) (Draxler and Rolph, 2003). Arriving heights were set at 50, 1000 and $2000 \mathrm{~m}$ and time at 12:00 GMT (05:00 p.m. local time). The Fig. $2 \mathrm{a}$ and $\mathrm{d}$ show the $50 \mathrm{~m}$ trajectories. The trajectories were subjectively classified in four groups:

Marine: trajectories at all arrival heights arriving from the west-south-southeast sector with no land contact during the last 10 days (Fig. 2a). Most of these trajectories originated south east of $\mathrm{MCOH}$ reaching the site after a clockwise turn during the last few days. All situations in this group $(N=95)$ occurred during the months June through September.

Arabian Sea: trajectories traversing the eastern parts of the Arabian Sea arriving at $\mathrm{MCOH}$ after possible land contact with western India or other mostly arid regions surrounding the Arabian Sea (Fig. 2b). The days in this group $(N=12)$ occurred in the months March, April and October.

Indian: trajectories having spent at least 2 of the last 10 days over polluted parts of south Asia and with at most 4 days over the ocean before reaching MCOH (Fig. 2c). The days in this group $(N=12)$ occurred during the winter months, December and January.

Mixed: trajectories which do not belong to either of the above three groups (Fig. 2d). Several of the trajectories shown in this figure look like they should belong to the Marine group. These were classified as Mixed because the trajectories for the different arrival heights were substantially different from each other. Because of its heterogeneity this trajectory group $(N=69)$ is not analysed in detail.

The air flow over the Maldives is dominated by the winter circulation during November-April bringing dry air from the Asian continent arriving at the Maldives from a northeasterly or northerly direction (cf. Fig. $2 b$ and c) and the monsoon circulation from June to September bringing moist air from the southern Indian Ocean (Fig. 2a).

\subsection{Statistical analysis}

Data (daily averaged) correlations were calculated using STATISTICA 6.0 in order to search for statistical, and possibly causal, relationships between two or more of the observed ionic constituents. This was done separately for the trajectory groups Marine, Arabian Sea and Indian. A principal component analysis (PCA) was also applied to the data. This is a simplified representation of the data, which identifies the relationship among the variables and provides indica-
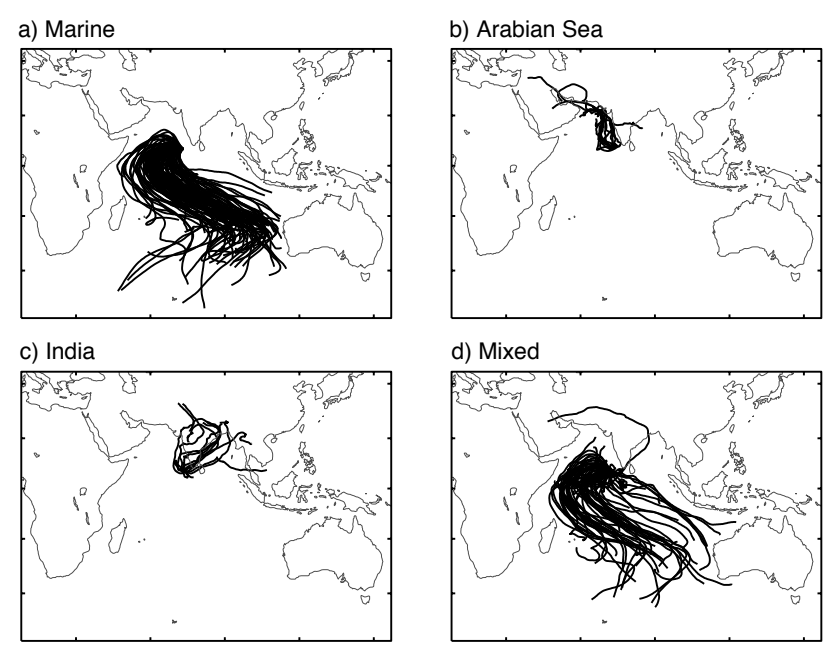

Fig. 2. Classification of trajectories arriving at $\mathrm{MCOH}$, (a) Marine, (b) Arabian Sea (c) Indian and (d) Mixed. For definitions see Sect. 2.4

tions of their source types based on the nature of factors obtained (Seto et al., 2000; Topcu et al., 2002; Semionov et al., 2003; Astel et al., 2004). In principle, PCA produces a linear combination of the variables, which explains a large fraction of the variance of the data. These linear combinations represent factors that are obtained by computing a correlation matrix between the variables. Varimax rotated mode of PCA was applied in this study. The software package used in this study is STATISTICA 6.0. The statistically significant rotated factor loadings ( $\geq 0.70$. marked bold) and the explained variance for the three trajectory groups are given in the tables shown in next section.

\section{Results and discussion}

\subsection{An overview of the precipitation chemistry data}

Figure 3 shows the data at a monthly resolution depicting individual events and volume weighted mean (VWM) values for each month. For obvious reasons the seasonal distribution of the number of observations is uneven with few measurements during the period December through May (no rainfall events at all for February, Fig. 3a). The components $\mathrm{NH}_{4}^{+}$ (Fig. 3c), $\mathrm{NO}_{3}^{-}$(Fig. 3g), nss-SO $\mathrm{SO}_{4}^{2-}$ (Fig. 3h) and $\mathrm{H}^{+}$(from pH, Fig. 3b) all show highest mean concentrations during December through March, indicating an impact of continental pollutants. The concentration of nss-Ca ${ }^{2+}$ (Fig. 3f), on the other hand, was highest in June and July. Possible reason for this seasonality will be discussed in Sect. 3.5. The concentration of both $\mathrm{K}^{+}$(Fig. 3d) and $\mathrm{Mg}^{2+}$ (Fig. 3e) showed a less clear-cut seasonal distribution. To evaluate possible source region for the precipitation collected at the $\mathrm{MCOH}$ 

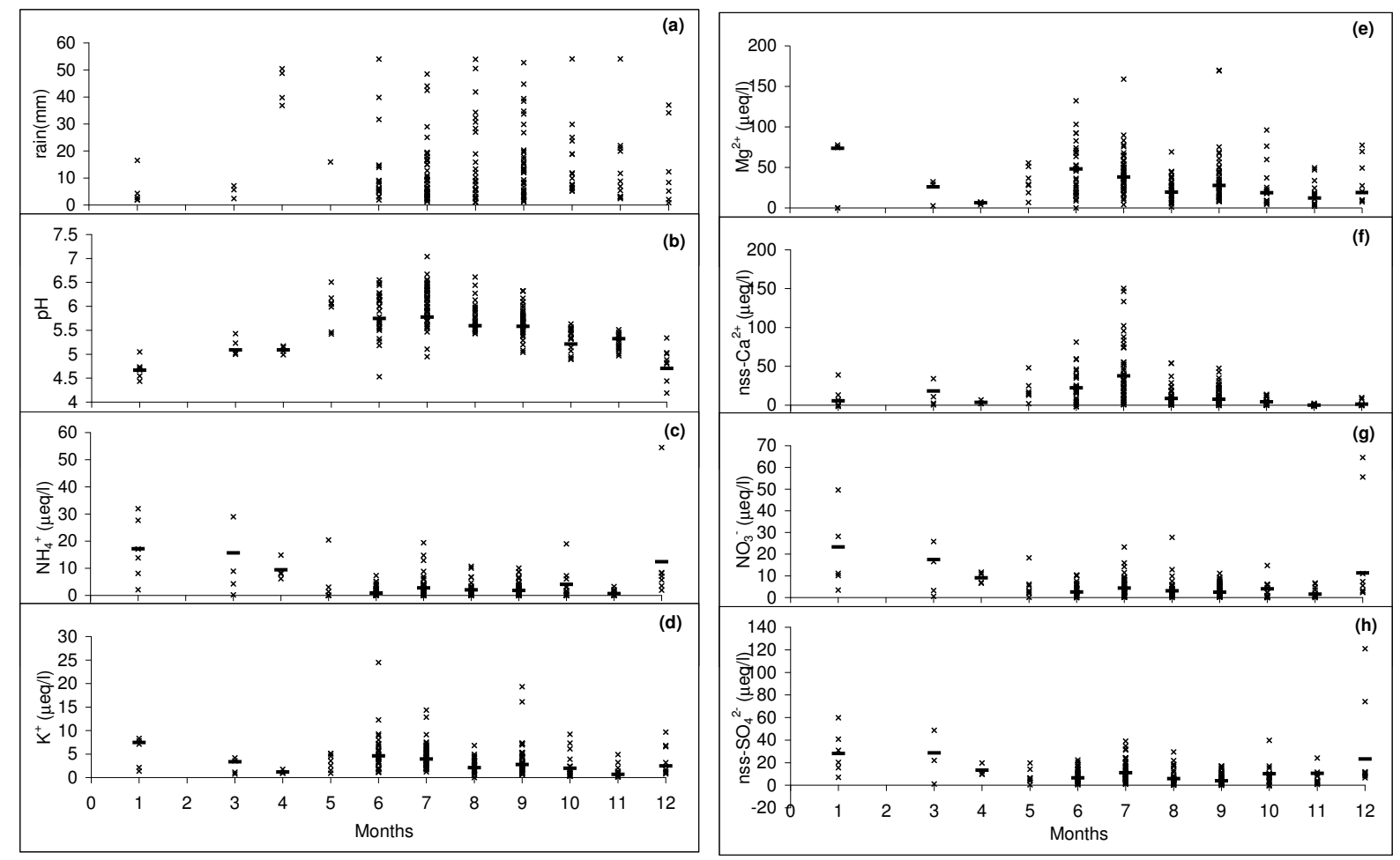

Fig. 3. Summary by month of measured quantities (a) rainfall amount (in mm), (b) $\mathrm{pH}$, (c) $\mathrm{NH}_{4}^{+}$, (d) $\mathrm{K}^{+}$, (e) $\mathrm{Mg}^{2+}$, (f) $\mathrm{nss}^{-\mathrm{Ca}}{ }^{2+}$, (g) $\mathrm{NO}_{3}^{-}$ and (h) nss- $\mathrm{SO}_{4}^{2-}$. Also shown as horizontal lines are volume weighted monthly mean values of ionic components (in $\mu$ eq/l).

observatory, the events were separated into three well defined trajectory groups, Marine (1), Arabian Sea (2) and Indian (3), and a less well defined group, Mixed (4), Volume weighted means were calculated for each group and are shown in Table 1, along with published VWM concentrations from some other remote locations for comparison. The concentrations of $\mathrm{NH}_{4}^{+}, \mathrm{NO}_{3}^{-}$and nss- $\mathrm{SO}_{4}^{2-}$ in the Marine group are comparable to those from Bermuda and Amsterdam Island whereas values in the Indian trajectory group are closer to those from Rural E India. Data on these three components in the Arabian Sea group fall in between those from the Marine and Indian groups. The high values of nss- $\mathrm{Ca}^{2+}$ observed in the Marine group stand out. For the three well-defined groups data from individual days were used to calculate correlations between the components (Tables 2, 4 and 6). The data in these groups were also subjected to a principal component analysis (PCA) (Tables 3, 5 and 7). A sea salt factor, including $\mathrm{Na}^{+}, \mathrm{K}^{+}, \mathrm{Mg}^{2+}$ and $\mathrm{Cl}^{-}$was evident in all three groups. Another consistent factor, including $\mathrm{NH}_{4}^{+}, \mathrm{NO}_{3}^{-}$and nss- $\mathrm{SO}_{4}^{2-}$, we interpret as being pollution. In the Arabian Sea group soil dust $\left(\mathrm{nss}-\mathrm{Ca}^{2+}\right)$ seems to be mixed into the latter factor. A third factor in the Marine group is clearly associated with nss- $\mathrm{Ca}^{2+}$ and $\mathrm{HCO}_{3}^{-}$. In the following sections we discuss the different components separately and attempt to derive possible sources.

\subsection{Sea salt}

The major sea salt components $\mathrm{Na}^{+}$and $\mathrm{Cl}^{-}$were found to be strongly correlated in all groups (Tables 2, 4 and 6). They were also the dominating rainwater components in all groups. The strong correlation between $\mathrm{Na}^{+}$and $\mathrm{Cl}^{-}$, and the similarity between the observed ratio $\mathrm{Cl}^{-} / \mathrm{Na}^{+}(1.14$, 1.12 and 1.12 in the three groups respectively) to that of seawater (1.17) indicate that both $\mathrm{Na}^{+}$and $\mathrm{Cl}^{-}$ions are primarily derived from marine sources (Keene et al., 1986). An association of $\mathrm{K}^{+}$and $\mathrm{Mg}^{2+}$ with $\mathrm{Na}^{+}$and $\mathrm{Cl}^{-}$in all three groups is obvious from the PCA analysis where these four components form an important factor. The variation in sea salt concentration between the trajectory groups (Table 1) is likely to be due to differences in the surface wind speed along the trajectories. As seen in Table 1 the nss-fractions of $\mathrm{K}^{+}$ and $\mathrm{Mg}^{2+}$ in all trajectory groups represent a small part of the total concentrations. As a consequence the measured values have a relatively large uncertainty making it difficult to draw any conclusions concerning their origin. In the Indian and Arabian Sea groups nss- $\mathrm{K}^{+}$values are likely to be influenced by anthropogenic biomass burning and combustion processes (Andreae, 1983; Norman et al., 2003). 
Table 1. Volume weighted mean concentrations in MCOH rainwater (this study) divided into trajectory groups and similar data for comparison from four other locations: A rural site near Bhubaneswar in E India (data from continental trajectories) taken from Norman et al. (2001), two sites on Bermuda (Galloway et al., 1988) and Amsterdam Island (Moody et al., 1991). Unit: $\mu$ eq $1^{-1}$.

\begin{tabular}{|c|c|c|c|c|c|c|c|c|}
\hline & Marine & India & $\begin{array}{r}\text { Arabian } \\
\text { Sea }\end{array}$ & Mixed & $\begin{array}{r}\text { Rural E } \\
\text { India }\end{array}$ & $\begin{array}{r}\text { Bermuda } \\
\text { HRT }\end{array}$ & $\begin{array}{r}\text { Bermuda } \\
\text { HP }\end{array}$ & $\begin{array}{r}\text { Amsterdam } \\
\text { Island }\end{array}$ \\
\hline net $\mathrm{H}^{+}$ & 0 & 10 & 6 & 0 & 0 & 11 & 11 & 8 \\
\hline net $\mathrm{HCO}_{3}^{-}$ & 22 & 0 & 0 & 14 & 0 & 0 & 0 & 0 \\
\hline $\mathrm{Na}^{+}$ & 170 & 146 & 43 & 82 & 11 & 105 & 168 & 269 \\
\hline $\mathrm{NH}_{4}^{+}$ & 2 & 15 & 9 & 3 & 33 & 3 & 3 & 2 \\
\hline $\mathrm{K}^{+{ }^{4}}$ & 4 & 4 & 2 & 2 & 3 & 3 & 4 & 6 \\
\hline$n s s-K^{+}$ & 0.3 & 1.1 & 0.8 & 0.1 & 2 & - & - & 0.1 \\
\hline $\mathrm{Mg}^{2+}$ & 40 & 39 & 11 & 20 & 5 & 24 & 37 & 60 \\
\hline nss- $\mathrm{Mg}^{2+}$ & 1 & 6 & 2 & 1 & 2 & - & - & -1 \\
\hline $\mathrm{Ca}^{2+}$ & 27 & 9 & 7 & 16 & 16 & 9 & 11 & 12 \\
\hline nss-Ca ${ }^{2+}$ & 20 & 3 & 5 & 12 & 16 & 4 & 4 & 0.4 \\
\hline MSA $* 100$ & 5 & 0 & 0 & 7 & - & - & - & - \\
\hline $\mathrm{Cl}^{-}$ & 195 & 164 & 49 & 93 & 13 & 125 & 194 & 318 \\
\hline $\mathrm{nss}_{-} \mathrm{Cl}^{-}$ & -4 & -6 & -2 & -2 & -1 & - & - & 4 \\
\hline $\mathrm{NO}_{3}^{-}$ & 3 & 18 & 9 & 3 & 16 & 4 & 4 & 2 \\
\hline $\mathrm{SO}_{4}^{2-}$ & 27 & 47 & 21 & 18 & 29 & 26 & 34 & 37 \\
\hline nss-SO ${ }_{4}^{2-}$ & 7 & 29 & 16 & 8 & 29 & 14 & 14 & 5 \\
\hline $\mathrm{pH}$ & 6.0 & 4.7 & 5.2 & 5.8 & 5.6 & - & - & - \\
\hline no. of samples & 95 & 12 & 12 & 69 & 41 & 127 & 126 & 179 \\
\hline
\end{tabular}

Table 2. Correlation coefficients for rainwater ionic components in the Marine trajectory group. Bold font indicates that the correlation is significant at $95 \%$ level.

\begin{tabular}{|c|c|c|c|c|c|c|c|c|c|c|c|}
\hline Marine & $\mathrm{H}^{+}$ & $\mathrm{Na}^{+}$ & $\mathrm{NH}_{4}^{+}$ & nss- $\mathrm{K}^{+}$ & nss-Mg ${ }^{2+}$ & nss-Ca ${ }^{2+}$ & MSA & $\mathrm{Cl}^{-}$ & $\mathrm{NO}_{3}^{-}$ & $\mathrm{HCO}_{3}^{-}$ & nss-SO ${ }_{4}^{2-}$ \\
\hline $\mathrm{H}^{+}$ & 1.00 & -0.12 & 0.05 & 0.05 & 0.07 & -0.16 & -0.05 & -0.13 & -0.06 & -0.15 & -0.06 \\
\hline $\mathrm{Na}^{+}$ & -0.12 & 1.00 & -0.05 & 0.07 & 0.21 & 0.19 & -0.07 & 1.00 & 0.23 & 0.16 & 0.08 \\
\hline $\mathrm{NH}_{4}^{+}$ & 0.05 & -0.05 & 1.00 & 0.49 & 0.05 & 0.03 & 0.23 & -0.04 & 0.67 & 0.01 & 0.56 \\
\hline $\mathrm{nss}_{-} \mathrm{K}^{+}$ & 0.05 & 0.07 & 0.49 & 1.00 & 0.02 & 0.09 & 0.13 & 0.06 & 0.56 & 0.02 & 0.49 \\
\hline nss- $\mathrm{Mg}^{2+}$ & 0.07 & 0.21 & 0.05 & 0.02 & 1.00 & 0.35 & -0.07 & 0.21 & 0.12 & 0.38 & 0.08 \\
\hline nss- $\mathrm{Ca}^{2+}$ & -0.16 & 0.19 & 0.03 & 0.09 & 0.35 & 1.00 & -0.08 & 0.19 & 0.34 & 0.95 & 0.61 \\
\hline MSA & -0.05 & -0.07 & 0.23 & 0.13 & -0.07 & -0.08 & 1.00 & -0.07 & 0.15 & -0.08 & 0.18 \\
\hline $\mathrm{Cl}^{-}$ & -0.13 & 1.00 & -0.04 & 0.06 & 0.21 & 0.19 & -0.07 & 1.00 & 0.24 & 0.17 & 0.09 \\
\hline $\mathrm{NO}_{3}^{-}$ & -0.06 & 0.23 & 0.67 & 0.56 & 0.12 & 0.34 & 0.15 & 0.24 & 1.00 & 0.28 & 0.73 \\
\hline $\mathrm{HCO}_{3}^{-}$ & -0.15 & 0.16 & 0.01 & 0.02 & 0.38 & 0.95 & -0.08 & 0.17 & 0.28 & 1.00 & 0.54 \\
\hline nss- $\mathrm{SO}_{4}^{2-}$ & -0.06 & 0.08 & 0.56 & 0.49 & 0.08 & 0.61 & 0.18 & 0.09 & 0.73 & 0.54 & 1.00 \\
\hline
\end{tabular}

\subsection{Sulfate and MSA}

In the Indian and Arabian Sea trajectory groups nss- $\mathrm{SO}_{4}^{2-}$ represents a large part of the total $\mathrm{SO}_{4}^{2-}$ concentration (Table 1). Both the PCA analysis (Tables 5 and 7) and the correlations with other components of likely anthropogenic components $\left(\mathrm{NH}_{4}^{+}, \mathrm{NO}_{3}^{-}\right.$; Tables 4 and 6) point towards a substantial influence from anthropogenic emissions in southern Asia and the Arabian peninsula. In the Marine group the concentration of nss- $\mathrm{SO}_{4}^{2-}$ is about $25 \%$ of the total $\mathrm{SO}_{4}^{2-}$. In order to estimate if the nss- $\mathrm{SO}_{4}^{2-}$ in Marine group could be derived from dimethyl sulphide (DMS), we calculated the molar ratio of MSA to nss- $\mathrm{SO}_{4}^{2-}$ in the collected rainwater. Several field studies have investigated the factors controlling the airborne particulate molar ratio of MSA to nss- $\mathrm{SO}_{4}^{2-}$ and found a negative temperature dependence (Bates et al., 1992; Ayers et al., 1996; Leck et al., 2002). The mean molar ratio value was around of $1.3 \%$ in this study, which is in agreement 


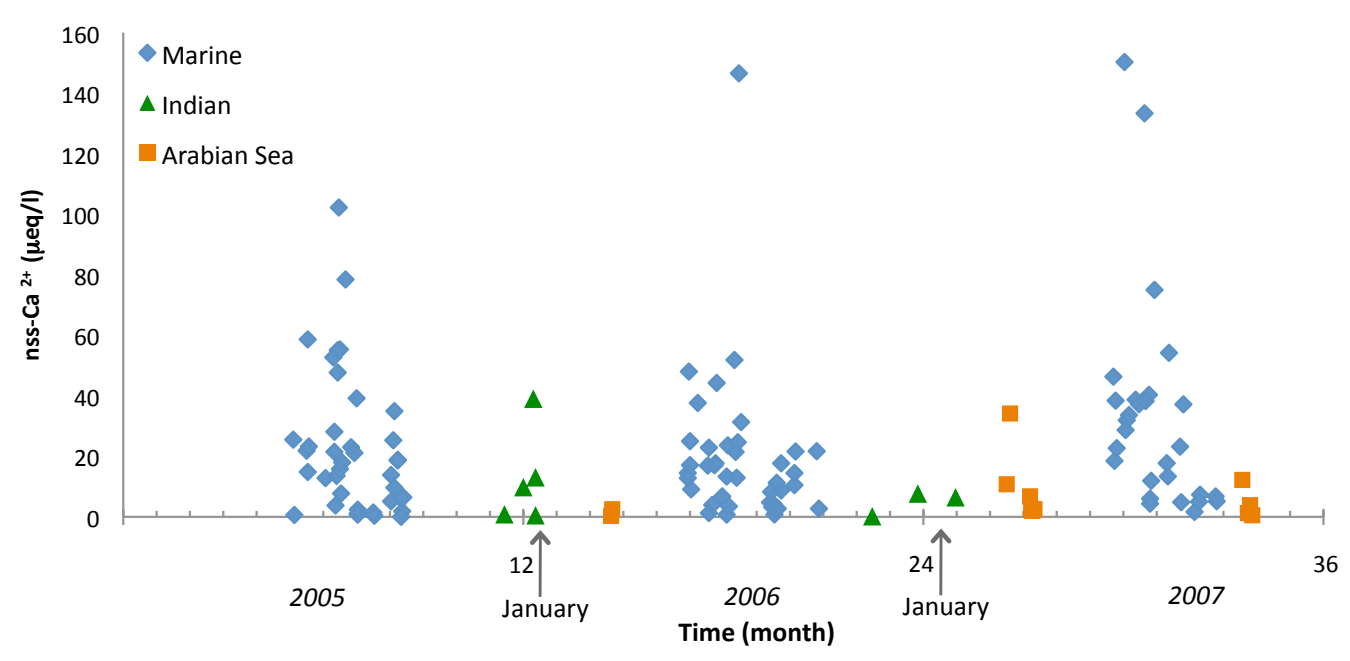

Fig. 4. Concentration of nss-Ca ${ }^{2+}\left(\right.$ in $\mu$ eq $\left.1^{-1}\right)$ as a function of time in the three trajectory groups Marine, Arabian Sea and Indian, defined in Sect. 2.4).

Table 3. Factor loadings and total variance identified in the Marine trajectory group. * Bold font indicates that the factor loading is significant at $95 \%$ level.

\begin{tabular}{lrrr}
\hline Marine & Factor 1 & Factor 2 & Factor 3 \\
\hline $\mathrm{Na}^{+}$ & $\mathbf{1 . 0 0}$ & 0.01 & 0.07 \\
$\mathrm{NH}_{4}^{+}$ & -0.06 & $\mathbf{0 . 9 2}$ & -0.11 \\
$\mathrm{~K}^{+}$ & $\mathbf{0 . 9 6}$ & 0.19 & 0.07 \\
$\mathrm{Mg}^{2+}$ & $\mathbf{0 . 9 9}$ & 0.01 & 0.11 \\
$\mathrm{nss}^{-} \mathrm{Ca}^{2+}$ & 0.12 & 0.13 & $\mathbf{0 . 9 7}$ \\
$\mathrm{Cl}^{-}$ & $\mathbf{0 . 9 9}$ & 0.02 & 0.08 \\
$\mathrm{NO}_{3}^{-}$ & 0.22 & $\mathbf{0 . 8 7}$ & 0.21 \\
$\mathrm{HCO}_{3}^{-}$ & 0.09 & 0.07 & $\mathbf{0 . 9 7}$ \\
nss-SO $_{4}^{2-}$ & 0.03 & $\mathbf{0 . 7 4}$ & 0.55 \\
$\%$ Total variance & 48 & 29 & 17 \\
\hline
\end{tabular}

with the estimate of 1 to $2 \%$ at $28^{\circ} \mathrm{C}$ (representative for the summer monsoon) given by Bates et al. (1992). This is somewhat lower than the 3\% reported by Norman et al. (2003) from ship measurements in an area south of $\mathrm{MCOH}$ in air that had been over the ocean for at least 10 days. We believe it to be likely that DMS is a source for the nss- $\mathrm{SO}_{4}^{2-} \mathrm{ob}-$ served in the Marine group but given the uncertainties in the underlying data, both in this study and in Norman et al., we refrain from drawing any firm conclusions regarding the influence of DMS derived $\mathrm{SO}_{4}^{2-}$. In trajectory group 3 (Indian) the molar ratio of MSA to nss- $\mathrm{SO}_{4}^{2-}$ ratio was only $0.003 \%$ indicating that DMS was an unimportant source. No MSA data are available for the Arabian Sea group.

\subsection{Nitrogen compounds}

Both $\mathrm{NO}_{3}^{-}$and $\mathrm{NH}_{4}^{+}$occur in higher concentration in the two groups with northerly flow compared to the Marine group (Table 1). The ratio between the mean concentrations in Indian group to that in the Marine group is 7 and 5.5 for $\mathrm{NH}_{4}^{+}$ and $\mathrm{NO}_{3}^{-}$, respectively. Both these ions have high loading in the "pollution factor" in the two northerly groups and also correlate well with nss- $\mathrm{SO}_{4}^{2-}$ in these groups. These facts point strongly at anthropogenic sources on the Asian continent. Substantial amounts of anthropogenic aerosol containing nitrogenous and sulphurous compounds are thus carried by the winds towards the study site in situations with northerly flows. Significant correlations between $\mathrm{NO}_{3}^{-}, \mathrm{NH}_{4}^{+}$ and nss- $\mathrm{SO}_{4}^{2-}$ are observed in the Marine trajectory group (Table 2). The PCA analysis shows a pollution factor also in this group (Table 3 ). This could indicate an anthropogenic influence even though the concentrations are much lower than in the other groups. Given that the 10 days trajectories arriving at Hanimadhoo did not show any recent contact with land, the most possible interpretation of these correlations in the Marine group is that there are co-located natural sources of $\mathrm{N}$ and $\mathrm{S}$ compounds associated with biological activity in the ocean surface layer. Nitrogen is a key element for algal metabolism because it is a main component of algal proteins and enzyme catalyst capacity, and often limits plant growth and biomass (e.g. Lapointe, 1987). Major sources of $\mathrm{NH}_{3}$ in remote marine surface water are degraded organic nitrogen compounds and excretion from zooplankton while sink pathways mainly include bacterial nitrification, uptake by phytoplankton and ventilation to the atmosphere (Bouwman et al., 1997; Norman and Leck, 2005). The correlation between $\mathrm{NH}_{4}^{+}$and nss- $\mathrm{SO}_{4}^{2-}$ could be due to an emission of $\mathrm{NH}_{3}$ that is limited by the amount of sulphuric acid formed 
Table 4. Correlation coefficients for rainwater ionic components in the Indian trajectory group. ${ }^{*}$ Bold font indicates that the correlation is significant at $95 \%$ level.

\begin{tabular}{|c|c|c|c|c|c|c|c|c|c|c|c|}
\hline Indian & $\mathrm{H}^{+}$ & $\mathrm{Na}^{+}$ & $\mathrm{NH}_{4}^{+}$ & nss- $\mathrm{K}^{+}$ & nss- $\mathrm{Mg}^{2+}$ & nss- $\mathrm{Ca}^{2+}$ & MSA & $\mathrm{Cl}^{-}$ & $\mathrm{NO}_{3}^{-}$ & $\mathrm{HCO}_{3}^{-}$ & nss- $\mathrm{SO}_{4}^{2-}$ \\
\hline $\mathrm{H}^{+}$ & 1.00 & 0.59 & 0.74 & 0.95 & 0.32 & 0.75 & 0.26 & 0.54 & 0.90 & 0.13 & 0.90 \\
\hline $\mathrm{Na}^{+}$ & 0.59 & 1.00 & 0.38 & 0.62 & 0.69 & 0.60 & 0.13 & 1.00 & 0.63 & 0.07 & 0.51 \\
\hline $\mathrm{NH}_{4}^{+}$ & 0.74 & 0.38 & 1.00 & 0.81 & 0.11 & 0.51 & 0.80 & 0.32 & 0.78 & 0.13 & 0.83 \\
\hline nss- $-\mathrm{K}^{+}$ & 0.95 & 0.62 & 0.81 & 1.00 & 0.25 & 0.61 & 0.34 & 0.57 & 0.84 & 0.05 & 0.96 \\
\hline nss- $\mathrm{Mg}^{2+}$ & 0.32 & 0.69 & 0.11 & 0.25 & 1.00 & 0.36 & -0.06 & 0.70 & 0.32 & 0.21 & 0.19 \\
\hline nss-Ca ${ }^{2+}$ & 0.75 & 0.60 & 0.51 & 0.61 & 0.36 & 1.00 & 0.30 & 0.56 & 0.92 & 0.27 & 0.56 \\
\hline MSA & 0.26 & 0.13 & 0.80 & 0.34 & -0.06 & 0.30 & 1.00 & 0.08 & 0.48 & 0.17 & 0.40 \\
\hline $\mathrm{Cl}^{-}$ & 0.54 & 1.00 & 0.32 & 0.57 & 0.70 & 0.56 & 0.08 & 1.00 & 0.58 & 0.06 & 0.46 \\
\hline $\mathrm{NO}_{3}^{-}$ & 0.90 & 0.63 & 0.78 & 0.84 & 0.32 & 0.92 & 0.48 & 0.58 & 1.00 & 0.20 & 0.81 \\
\hline $\mathrm{HCO}_{3}^{-}$ & 0.13 & 0.07 & 0.13 & 0.05 & 0.21 & 0.27 & 0.17 & 0.06 & 0.20 & 1.00 & -0.09 \\
\hline nss- $\mathrm{SO}_{4}^{2-}$ & 0.90 & 0.51 & 0.83 & 0.96 & 0.19 & 0.56 & 0.40 & 0.46 & 0.81 & -0.09 & 1.00 \\
\hline
\end{tabular}

Table 5. Factor loadings and total variance identified in the Indian trajectory group. * Bold font indicates that the factor loading is significant at $95 \%$ level.

\begin{tabular}{lrrr}
\hline Indian & Factor 1 & Factor 2 & Factor 3 \\
\hline $\mathrm{Na}^{+}$ & $\mathbf{0 . 9 6}$ & 0.27 & 0.03 \\
$\mathrm{NH}_{4}^{+}$ & 0.12 & $\mathbf{0 . 9 2}$ & 0.04 \\
$\mathrm{~K}^{+}$ & $\mathbf{0 . 8 8}$ & 0.46 & 0.01 \\
$\mathrm{Mg}^{2+}$ & $\mathbf{0 . 9 6}$ & 0.21 & 0.07 \\
$\mathrm{nss}^{-} \mathrm{Ca}^{2+}$ & 0.46 & 0.64 & 0.37 \\
$\mathrm{Cl}^{-}$ & $\mathbf{0 . 9 8}$ & 0.20 & 0.02 \\
$\mathrm{NO}_{3}^{-}$ & 0.42 & $\mathbf{0 . 8 5}$ & 0.23 \\
$\mathrm{HCO}_{3}^{-}$ & 0.02 & 0.03 & $\mathbf{0 . 9 7}$ \\
nss-SO & 0.29 & $\mathbf{0 . 8 9}$ & -0.19 \\
\% Total variance & 64 & 16 & 12 \\
\hline
\end{tabular}

in the marine boundary layer, in agreement with earlier suggestions by Norman and Leck (2005).

\section{$3.5 \mathrm{nss}^{-\mathrm{Ca}^{2+}}$}

In the Marine and Arabian Sea trajectory groups the concentration of nss-Ca ${ }^{2+}$ is more than half of the total $\mathrm{Ca}^{2+}$ clearly indicating significant sources other than sea salt. The concentration of nss- $\mathrm{Ca}^{2+}$ in the Marine group was surprisingly high - on average four times higher than in the Arabian Sea group and seven times higher than in the Indian group. Figure 4 shows that the high mean values in the Marine group are not caused by a few high outliers but are systematic. If continental soil-dust were the main source one would have expected the highest concentrations associated with the two northerly trajectory groups. In the Marine group there is a high correlation between nss- $\mathrm{Ca}^{2+}$ and $\mathrm{HCO}_{3}^{-}\left(r^{2}=0.95\right)$ indicating that most of the nss- $\mathrm{Ca}^{2+}$ is derived from calcium carbonate, $\mathrm{CaCO}_{3}$. Analysis and sampling errors including contamination by local soil dust during dry periods are very unlikely to explain these high concentrations of nss- $\mathrm{Ca}^{2+}$, see Sect. 2.3. If local dust from the island had been an important source, one would have expected larger fraction of nss- $\mathrm{Ca}^{2+}$ in aerosol particles collected at our site than in rainwater since rainwater collects much of its aerosol material at cloud levels where local contamination is much less likely. According to Granat et al. (2010), such larger influence was not observed. Several studies have attributed $\mathrm{Ca}^{2+}$ enrichment in marine aerosol and precipitation to transported crustal dust from distant continents. A model study over Indian Ocean (Adhikary et al., 2007) suggested that aerosol mass composition at Hanimadhoo during the monsoon season was dominated by mineral dust in both coarse and fine modes. The dust was transported eastwards from Africa and then brought into the Asian monsoon circulation. In the present study, the 10 days trajectories arriving at Hanimadhoo do not show any recent contact with land. We extended trajectories for days with particularly high concentrations of $\mathrm{Ca}^{2+}$ in rain to 20 days and saw a few cases where they originate close to Australia. A potential source of the high concentrations of nss- $\mathrm{Ca}^{2+}$ in the Marine group is Ca-enriched sea spray particles formed around Hanimaadhoo and other upstream Maldivian islands. Such enrichment could maybe be expected from erosion of coral reef material. We collected a few sea water samples near the shore of the Hanimaadhoo island but found no signs of substantially elevated concentrations of $\mathrm{Ca}^{2+}$. Direct emission of calcareous (containing $\mathrm{CaCO}_{3}$ ) plankton debris in association with marine aerosol production from bursting bubbles has been suggested to be a significant in situ source in the marine atmosphere (Sievering et al., 2004). Another possibility of $\mathrm{Ca}^{2+}$ enrichment in marine air could be through its association with organic matter (Keene et al., 2007). One further explanation that extends the conclusion by Keene et 
Table 6. Correlation coefficients for rainwater ionic components in the Arabian Sea trajectory group. * Bold font indicates that the correlation is significant at $95 \%$ level.

\begin{tabular}{|c|c|c|c|c|c|c|c|c|c|c|c|}
\hline Arabian Sea & $\mathrm{H}^{+}$ & $\mathrm{Na}^{+}$ & $\mathrm{NH}_{4}^{+}$ & $\mathrm{nss}-\mathrm{K}^{+}$ & nss-Mg ${ }^{2+}$ & nss- $-\mathrm{Ca}^{2+}$ & MSA & $\mathrm{Cl}^{-}$ & $\mathrm{NO}_{3}^{-}$ & $\mathrm{HCO}_{3}^{-}$ & nss-SO ${ }_{4}^{2-}$ \\
\hline $\mathrm{H}^{+}$ & 1.00 & -0.26 & 0.27 & 0.38 & 0.01 & 0.03 & & -0.26 & 0.29 & -0.02 & 0.30 \\
\hline $\mathrm{Na}^{+}$ & -0.26 & 1.00 & -0.04 & -0.02 & 0.16 & 0.24 & & 1.00 & 0.18 & 0.09 & 0.13 \\
\hline $\mathrm{NH}_{4}^{+}$ & 0.27 & -0.04 & 1.00 & 0.96 & 0.86 & 0.90 & & -0.06 & 0.91 & -0.51 & 0.95 \\
\hline$n s s-K^{+}$ & 0.38 & -0.02 & 0.96 & 1.00 & 0.87 & 0.89 & & -0.03 & 0.91 & -0.40 & 0.95 \\
\hline nss-Mg ${ }^{2+}$ & 0.01 & 0.16 & 0.86 & 0.87 & 1.00 & 0.98 & & 0.14 & 0.86 & -0.39 & 0.86 \\
\hline nss-Ca ${ }^{2+}$ & 0.03 & 0.24 & 0.90 & 0.89 & 0.98 & 1.00 & & 0.22 & 0.88 & -0.36 & 0.90 \\
\hline MSA & & & & & & & 1.00 & & & & \\
\hline $\mathrm{Cl}^{-}$ & -0.26 & 1.00 & -0.06 & -0.03 & 0.14 & 0.22 & & 1.00 & 0.16 & 0.10 & 0.11 \\
\hline $\mathrm{NO}_{3}^{-}$ & 0.29 & 0.18 & 0.91 & 0.91 & 0.86 & 0.88 & & 0.16 & 1.00 & -0.64 & 0.93 \\
\hline $\mathrm{HCO}_{3}^{-}$ & -0.02 & 0.09 & -0.51 & -0.40 & -0.39 & -0.36 & & 0.10 & -0.64 & 1.00 & -0.40 \\
\hline nss-SO & 0.30 & 0.13 & 0.95 & 0.95 & 0.86 & 0.90 & & 0.11 & 0.93 & -0.40 & 1.00 \\
\hline
\end{tabular}

Table 7. Factor loadings and total variance identified in the Arabian Sea data set. * Bold font indicates that the factor loading is significant at $95 \%$ level.

\begin{tabular}{lrr}
\hline Arabian sea & Factor 1 & Factor 2 \\
\hline $\mathrm{Na}^{+}$ & -0.05 & $\mathbf{0 . 9 9}$ \\
$\mathrm{NH}_{4}^{+}$ & $\mathbf{0 . 9 8}$ & 0.02 \\
$\mathrm{~K}^{+}$ & 0.50 & $\mathbf{0 . 8 6}$ \\
$\mathrm{Mg}^{2+}$ & 0.23 & $\mathbf{0 . 9 7}$ \\
$\mathrm{nss}^{-} \mathrm{Ca}^{2+}$ & $\mathbf{0 . 8 9}$ & 0.31 \\
$\mathrm{Cl}^{-}$ & -0.06 & $\mathbf{0 . 9 9}$ \\
$\mathrm{NO}_{3}^{-}$ & $\mathbf{0 . 9 6}$ & 0.22 \\
$\mathrm{HCO}_{3}^{-}$ & -0.63 & 0.14 \\
nss-SO & $\mathbf{0 . 9 4}$ & 0.19 \\
$\%$ Total variance & 58 & 32 \\
\hline
\end{tabular}

al., is the possibility that the nss- $\mathrm{Ca}^{2+}$ originates from exopolymer gels or marine gels (Decho, 1990) consisting of very hydrophilic polysaccharides inter-bridged with divalent ions, preferable $\mathrm{Ca}^{2+}$, present in the ocean surface layer (uppermost $\mathrm{mm}$ ). Such gels have been shown to be an important component of the tropical marine aerosols (Leck and Bigg, 2008; Bigg and Leck, 2008; Hawkins and Russell, 2010). The non-existing correlation between nss- $\mathrm{Ca}^{2+}$ and MSA in the Marine group indicates that if a pelagic biological source of nssCa ${ }^{2+}$ is important it must be associated with biological processes of a different kind (Leck and Bigg, 2007) compared to those that give rise to DMS emissions. We have looked for signs of high biological productivity in the upwind regions (areas covered by the ten day trajectories, cf. Fig. 2a) using MODIS aerosol optical depth measurements. Unfortunately, this particular study was inconclusive in that much of the area was cloudy and poorly covered by the satel- lite measurements. The conclusion from this section is that the unexpectedly high concentrations of nss- $\mathrm{Ca}^{2+}$ in the marine group remain to be better determined.

\section{$3.6 \mathrm{pH}$}

The frequency distributions of $\mathrm{pH}$ in the different groups are shown in Fig. 5a, b and c. The rainwater $\mathrm{pH}$ varies systematically between the three trajectory groups with the lowest volume weighted mean value ranging from 4.7 in the Indian group (Fig. 5b) to 6.0 in the Marine group (Fig. 5a). A pH value as low as 4.0 was recorded on one occasion with air flow from the Indian continent. The $\mathrm{pH}$ values are determined by a balance between acids - as seen from nss- $\mathrm{SO}_{4}^{2-}$ and $\mathrm{NO}_{3}^{-}-$and neutralizers such as carbonate and $\mathrm{NH}_{3}$ as seen from the concentration of nss- $\mathrm{Ca}^{2+}$ and $\mathrm{NH}_{4}^{+}$in the collected samples. It should be noted that the number of rainfall days is much smaller in the two groups with northerly flow than in the Marine group. A comparison with $\mathrm{pH}$ values measured in rain falling in the Indian subcontinent during winter season - e.g. typical values $>6.0$ at rural sites in India (Kulshrestha et al., 2005) - reveals that $\mathrm{pH}$ has a tendency to decrease as air is transported out over the Bay of Bengal and the Indian Ocean. The main reason is probably that the concentration of $\mathrm{CaCO}_{3}$ from soil dust - which occurs mainly in the coarse particle mode, Granat et al. (2010) - decreases more rapidly than the concentration of the acidifying components sulfuric and nitric acids of which at least the sulfuric acid is predominantly associated with the fine particle mode. A similar observation has been made previously by Kulshrestha et al. (2001), Granat et al. (2002) and Norman et al. (2003).

\subsection{Wet deposition}

In this section we consider the amount of the various components in rainwater that is deposited each month, Table 8 . The 
Table 8. Wet deposition of net acidity and net alkalinity (in $\mathrm{mmol} \mathrm{m}^{-2}$ ) and other rainwater components (in $\mathrm{mg} \mathrm{m}^{-2}$ ) by month and as annual total. ${ }^{*}$ Net acidity and net alkalinity deposition is obtained by summation over daily values with either $\mathrm{H}^{+}$deposition (as positive) or $\mathrm{HCO}_{3}^{-}$deposition (as negative). Monthly total is net- $\mathrm{H}^{+}$if positive otherwise net- $\mathrm{HCO}_{3}^{-}$.

\begin{tabular}{|c|c|c|c|c|c|c|c|c|c|c|c|c|c|}
\hline Months & $\mathrm{mm}$ rain & net $-\mathrm{H}^{+}$ & net - $\mathrm{HCO}_{3}^{-}$ & $\mathrm{Na}^{+}$ & $\mathrm{NH}_{4}^{+}-\mathrm{N}$ & $\mathrm{K}^{+}$ & $\mathrm{Mg}^{2+}$ & $\mathrm{Ca}^{2+}$ & MSA & $\mathrm{Cl}^{-}$ & $\mathrm{NO}_{3}^{-}-\mathrm{N}$ & $\mathrm{SO}_{4}^{2-}-\mathrm{S}$ & $n s s-\mathrm{SO}_{4}^{2-}-\mathrm{S}$ \\
\hline January & 14 & 0.2 & & 85 & 3 & 4 & 12 & 5 & 0.0 & 145 & 4 & 13 & 6 \\
\hline February & 0 & & & & & & & & & & & & \\
\hline March & 8 & 0.0 & & 14 & 2 & 1 & 2 & 3 & 0.0 & 25 & 2 & 5 & 4 \\
\hline April & 88 & 1 & & 45 & 12 & 4 & 7 & 8 & 0.0 & 75 & 11 & 22 & 19 \\
\hline May & 8 & & 0.0 & 25 & 2 & 1 & 3 & 3 & 0.0 & 45 & 2 & 5 & 3 \\
\hline June & 83 & & 1 & 400 & 1 & 15 & 50 & 53 & 0.1 & 700 & 3 & 40 & 9 \\
\hline July & 176 & & 8 & 633 & 7 & 27 & 80 & 157 & 2.5 & 1167 & 11 & 87 & 31 \\
\hline August & 148 & & 1 & 283 & 4 & 12 & 37 & 37 & 0.8 & 500 & 6 & 37 & 14 \\
\hline September & 217 & & 2 & 600 & 6 & 24 & 73 & 57 & 0.6 & 1033 & 7 & 63 & 14 \\
\hline October & 85 & & 0.1 & 153 & 5 & 7 & 19 & 13 & 0.0 & 270 & 5 & 27 & 14 \\
\hline November & 54 & & 1 & 60 & 1 & 1 & 8 & 2 & 0.0 & 107 & 1 & 14 & 9 \\
\hline December & 33 & 0.2 & & 57 & 6 & 3 & 8 & 3 & 0.0 & 97 & 5 & 17 & 12 \\
\hline Annual Total & 913 & & 12 & 2355 & 46 & 99 & 299 & 340 & 4 & 4163 & 58 & 329 & 133 \\
\hline
\end{tabular}

wet deposition is obtained as the product of the measured concentration in the rainwater and the amount of rain measured in the precipitation chemistry sampler. By providing data on input of both nutrients - e.g. nitrogen - and potentially harmful components - e.g. acidity - this information can be of considerable importance for studies of Maldivian ecosystems. However, deposition associated with rainwater (wet deposition) is only one of the pathways by which ecosystems can receive input from the atmosphere. Other processes include direct uptake of gases and particulate matter from the air (dry deposition) and deposition of spray droplets from the surf on the windward side of the island. Our data do not allow reliable quantitative estimates of these additional deposition processes but rough estimates indicate that the dry deposition of gaseous and particle-bound sulfur and nitrogen compounds is much less important than wet deposition, at least on an annual basis. A limited number of measurements of the concentration of $\mathrm{SO}_{2}$ and nitric acid $\left(\mathrm{HNO}_{3}\right)$ at $\mathrm{MCOH}$ during the monsoon period makes it possible to estimate an approximate magnitude of the dry deposition of these gases. With a typical concentration for $\mathrm{SO}_{2}$ of $1.5 \mathrm{nmol} \mathrm{m}^{-3}$ and for $\mathrm{HNO}_{3}$ of $0.4 \mathrm{nmol} \mathrm{m}^{-3}$ and dry deposition velocities of 1 and $4 \mathrm{~cm} \mathrm{~s}^{-1}$, respectively the dry deposition flux for these gases is two orders of magnitude smaller than the corresponding wet deposition values. Table 8 shows that the annual cycle of wet deposition for most components observed is characterized by a maximum during the monsoon season (June-September) obviously associated with the maximum in rainfall amount during this season. The deposition of $\mathrm{NH}_{4}^{+}, \mathrm{NO}_{3}^{-}$and nss- $\mathrm{SO}_{4}^{2-}$ has a more even seasonal distribution, with higher concentrations during the winter season being balanced by lower rainfall amounts. Input of net acidity only occurs during the winter season (December-April). The alkaline nature of the rainwater (positive values of net $\mathrm{HCO}_{3}^{-}$) during the monsoon season seems to be due to al- kali associated with $\mathrm{Ca}^{2+}$ and low concentration of acidifying components. The contribution from $\mathrm{NH}_{3}$, as viewed from the $\mathrm{NH}_{4}^{+}$concentration, is small during the summer monsoon season. The annual wet deposition of $\mathrm{NH}_{4}^{+}, \mathrm{NO}_{3}^{-}$and nss- $\mathrm{SO}_{4}^{2-}$ at $\mathrm{MCOH}$ are about a factor of three lower than the corresponding values given by Kulshrestha et al. (2005) as median for rural sites in India. Substantially lower about a factor of two to five - annual wet deposition values for these three compounds have been reported from Amsterdam Island in the southern Indian Ocean (E. Baboukas, personal communication, 2000). In order to judge the ecological significance of the wet deposition values measured at $\mathrm{MCOH}$, information is needed on the status of the Maldivian ecosystems and the characteristics of the soils. Any negative effects due to eutrophication (over-fertilization) through excessive nitrogen deposition are unlikely. Even if an additional contribution from dry deposition of nitrogen compounds is included the total nitrogen input to Maldivian ecosystems is likely to be well below the so called "critical load" for nitrogen deposition which in many European and North American terrestrial and aquatic ecosystems has been estimated to be above $500 \mathrm{mgN} \mathrm{m}^{-2} \mathrm{yr}^{-1}$ (Bobbink et al., 2010). Still, the wet deposition of nitrogen measured at $\mathrm{MCOH}$ clearly indicates a substantial nutrient input to Maldivian terrestrial ecosystems.

\section{Summary and conclusions}

This paper summarizes the results of 30 months of data on the chemical composition of precipitation at the $\mathrm{MCOH}$ site in the northern Indian Ocean. The measurement period includes both the period June-September with air arriving from more southerly parts of the Indian Ocean (Marine trajectory group) and the period November-April with air flow from the 

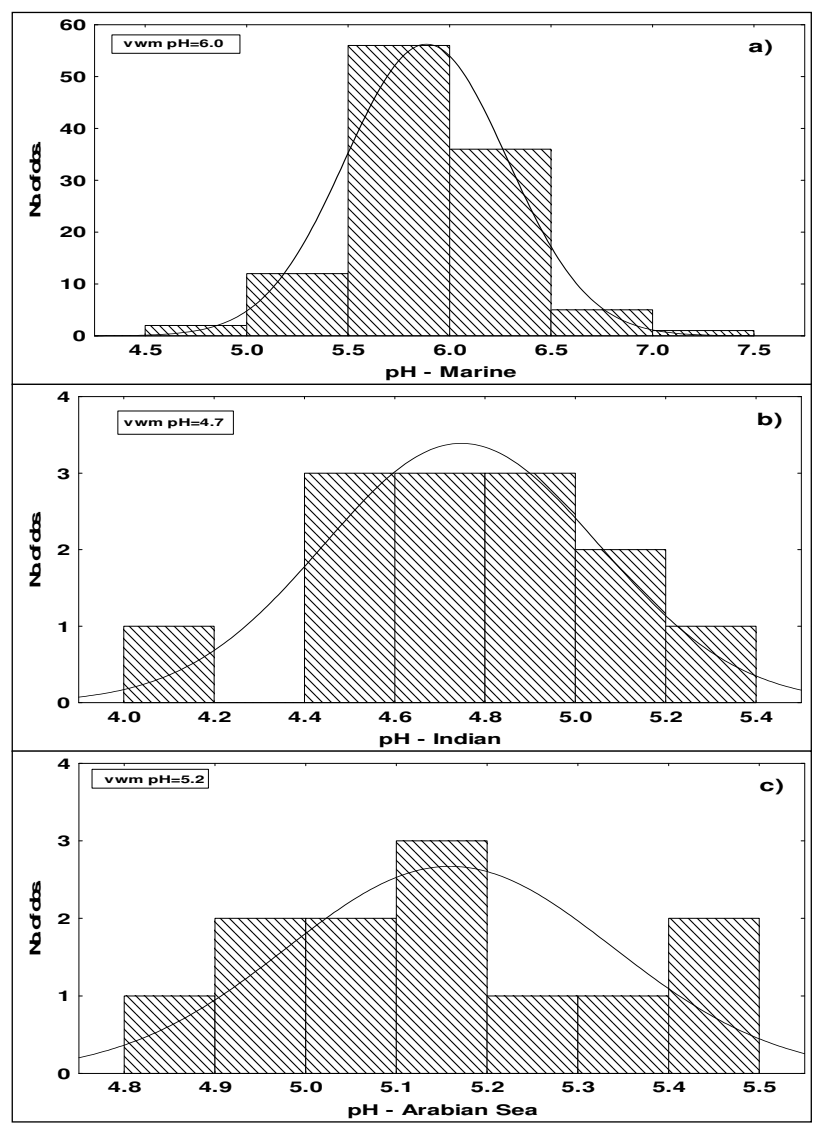

Fig. 5. Frequency distributions of $\mathrm{pH}$ in (a) Marine, (b) Indian and (c) Arabian Sea trajectory groups.

Indian subcontinent (Indian). A third group was also identified with trajectories emanating from the parts of the Arabian Sea and adjacent continental areas. For nss- $\mathrm{SO}_{4}^{2-}, \mathrm{NO}_{3}^{-}$ and $\mathrm{NH}_{4}^{+}$the concentrations in the Indian group were more than four times higher than in the Marine group, indicating a strong anthropogenic influence in the Indian group. This conclusion was supported by factor analysis and by a high correlation between these three compounds. In the Arabian Sea group the corresponding concentrations fell in between those in the Marine and Indian groups. Rainwater $\mathrm{pH}$ was substantially lower in air coming from the Indian subcontinent (mean $\mathrm{pH}=4.7$ in trajectory group "Indian") than in the monsoon air (6.0 in trajectory group "Marine"). On one occasion in the "Indian" group the $\mathrm{pH}$ was as low as 4.0. This is much lower than what is normally recorded in rainfall on the Indian Subcontinent. A systematic decrease in $\mathrm{pH}$ seems to occur in air transported out over the Bay of Bengal and the Indian Ocean during the winter season possibly caused by a more rapid decrease in the concentration of alkaline soil dust (coarse mode particles) than of the acidifying sulfur and nitrogen compounds (fine mode). In all trajectory groups $\mathrm{Cl}^{-}$ and $\mathrm{Na}^{+}$were the most abundant components. These ions were also highly correlated and their ratio was close to that found in seawater. A comparison with $\mathrm{Na}^{+}$showed that also for several other components an appreciable part of the concentration was derived from sea-salt. The concentration of the non sea salt $\mathrm{SO}_{4}^{2-}\left(\mathrm{nss}-\mathrm{SO}_{4}^{2-}\right.$ ) was lower in the Marine group than in the Indian group, by a factor of four. The concentrations of nss- $\mathrm{SO}_{4}^{2-}, \mathrm{NO}_{3}^{-}$and $\mathrm{NH}_{4}^{+}$were well correlated also in the Marine group and the PCA analysis showed a factor similar to the pollution factor seen in the Indian and Arabian Sea groups. One possible interpretation is that the air in the Marine group contains traces of pollution from distant sources. An alternative possibility might be that there are co-located natural sources associated with areas of high biological productivity in ocean surface waters. The latter interpretation has some support from our measurements of MSA which indicated that DMS from the ocean is likely to have made a contribution to the concentration of nss- $\mathrm{SO}_{4}^{2}$ in this group. The high concentration of nss- $\mathrm{Ca}^{2+}$ in the Marine group - a factor of four to seven higher than in groups "Arabian Sea" and "Indian" - is intriguing. With the available observations in this study the source of this nss- $\mathrm{Ca}^{2+}$ could not be well determined. Long-range transport of soil dust, as suggested by Adhikary et al. (2007) is one possibility although it is not well supported by our trajectory analysis. We discuss other possibilities, including soil derived dust from nearby islands, local sea spray containing elevated levels of $\mathrm{Ca}^{2+}$ from erosion of coral reefs and calcareous $\left(\mathrm{CaCO}_{3}\right)$ plankton debris and exopolymer gels emitted from the ocean surface. The annual wet deposition of $\mathrm{NO}_{3}^{-}, \mathrm{NH}_{4}^{+}$and nss$\mathrm{SO}_{4}^{2-}$ at $\mathrm{MCOH}$ is about a factor of three lower than observed at rural sites in India. The corresponding values at the remote Amsterdam Island in the southern Indian Ocean are a factor of two to five lower than those observed at $\mathrm{MCOH}$. This indicates that the chemical climate of the Maldives is affected by pollution sources on the Asian continent during the winter season. The atmospheric deposition of nitrogen is likely to represent an important input of nutrients to marine and terrestrial ecosystems in the Maldives.

Acknowledgements. We would like to acknowledge the valuable logistical support of the Government of the Republic of Maldives. This work is part of the international Atmospheric Brown Cloud $(\mathrm{ABC})$ project and has been funded mainly by the Swedish International Development Cooperation Agency (Sida). The following people have provided technical support in connection with the sampling and chemical analyses: staff at MCOH and Agneta Öhrström, Maria Larsson and Leif Bäcklin at MISU.

Edited by: A. Pszenny 


\section{References}

Adhikary, B., Carmichael, G. R., Tang, Y., Leung, L. R., Qian, Y., Schauer, J. J., Stone, E. A., Ramanathan, V., and Ramana, M. V.: Characterization of the seasonal cycle of south Asian aerosols: A regional-scale modelling analysis, J. Geophys. Res., 112, D22S22, doi:10.1029/2006JD008143, 2007.

Andreae, M. O.: Soot carbon and excess fine potassium: long-range transport of combustion-derived aerosols, Science, 220, 11481151, 1983.

Astel, A., Mazerski, J., Polkowska, Z., and Namieśnik, J.: Application of PCA and time series analysis in studies of precipitation in Tricity (Poland), Adv. Environ. Res., 8, 337-349, 2004.

Ayers, G. P., Cainey, J. M., Granek, H., and Leck, C.: Dimethylsulfide oxidation and the ratio of methansulfonate to non seasalt sulfate in the marine aerosol, J. Atmos. Chem., 25, 307-325, 1996.

Bates, T. S., Calhoun, J. A., and Quinn, P. K.: Variations in the methansulfonate to sulfate molar ratio in submicrometer marine aerosol particles over the south Pacific Ocean, J. Geophys. Res., 9, 9859-9865, 1992.

Bigg, E. K. and Leck, C.: The composition of fragments of bubbles bursting at the ocean surface, J. Geophys. Res., 113, D11209, doi:10.1029/2007JD009078, 2008.

Blanchard, D. C.: The electrification of the atmosphere by particles from bubbles in the sea, in: Progress in Oceanography, edited by: Sears, M., Elsevier, New York, 73-202, 1963.

Bobbink, R., Hicks, K., Galloway, J., Spranger, T., Alkemade, R., Ashmore, M., Bustamante, M., Cinderby, S., Davidson, E., Dentener, F., Emmett, B., Erisman, J. W., Fenn, M., Gilliam, F., Nordin, A., Pardo, L., and De Vries, W.: Global assessment of nitrogen deposition effects on terrestrial plant diversity, A synthesis, Ecol. Appl., 20(1), 30-59, 2010.

Bouwman, A. F., Lee, D. S., Asman, W. A. H., Dentener, F. J., Van Der Hoek, K. W., and Olivier, J. G. J.: A global high resolution emission inventory for ammonia, Global Biogeochem. Cy., 11, 561-587, 1997.

Budhavant, K. B., Rao, P. S. P., Safai, P. D., and Ali, K.: Chemistry of Monsoon and Post-Monsoon Rains at a High Altitude Location, Sinhagad, India, Aerosol Air Qual. Res., 9(1), 65-79, 2009.

Corrigan, C. E., Ramanathan, V., and Schauer, J. J.: Impact of monsoon transitions on the physical and optical properties of aerosols, J. Geophys. Res., 111, D18208, doi:10.1029/2005JD006370, 2006.

Corrigan, C. E., Roberts, G. C., Ramana, M. V., Kim, D., and Ramanathan, V.: Capturing vertical profiles of aerosols and black carbon over the Indian Ocean using autonomous unmanned aerial vehicles, Atmos. Chem. Phys., 8, 737-747, doi:10.5194/acp-8-737-2008, 2008.

Decho, A. W.: Microbial exopolymer secretions in ocean environments: Their role(s) in food webs and marine processes, Oceanogr. Mar. Biol., 28, 73-153, 1990.

Draxler, R. and Rolph, G.: Hysplit (hybrid single-particle lagrangian integrated trajectory) model access via NOAA arl ready, Tech. rep., NOAA Air Resources Laboratory, Silver Spring, MD, 2003.

EANET (Acid Deposition Monitoring Network in East Asia), Report of the Inter-laboratory Comparison Project 2007, http:// www.eanet.cc/product.html, 2008.

Gabriel, R., Mayol-Bracero, O. L., and Andreae M. O.: Chemical characterization of submicron aerosol particles collected over the Indian Ocean, J. Geophys. Res., 107(D19), 8005, doi:10.1029/2000JD000034, 2002.

Galloway, J. N., Tokos, J. J., Knap, A. H:, and Keene, W. C.: Local influences on the composition of precipitation on Bermuda, Tellus, 40B, 178-188, 1988.

Gillett, R. W. and Ayers, G. P.: The use of thymol as a biocide in rainwater samples, Atmos. Environ., 25(12), 2677-2681. 1991.

Granat, L., Norman, M., Leck, C., Kulshrestha, U. C., and Rodhe, H.: Wet scavenging of sulfur compounds and other constituents during the Indian Ocean Experiment (INDOEX), J. Geophys. Res., 107(D19), 8025, doi:10.1029/2001JD000499, 2002.

Granat, L., Engstrom, J. E., Praveen, S., and Rodhe, H.: Light Absorbing Material (Soot) in Rainwater and in Aerosol Particles in the Maldives, J. Geophys. Res., 115, D16307, doi:10.1029/2009JD013768, 2010.

Guazzotti, S. A., Coffee, K. R., and Prather, K. A.: Continuous measurements of size-resolved particle chemistry during INDOEX intensive field phase 99, J. Geophys. Res., 106(D22), 2860728627, 2001.

Guazzotti, S. A., Suess, D. T., Coffee, K. R.., Quinn, P. K., Bates, T. S., Wisthaler, A., Hansel, A., Ball, W. P., Dickerson, R. R., Neusuß, C., Crutzen, P. J., and Prather, K. A.: Characterization of carbonaceous aerosols outflow from India and Arabia: Biomass/biofuel burning and fossil fuel combustion, J. Geophys. Res., 108(D15), 4485, doi:10.1029/2002JD003277, 2003.

Hawkins, L.N. and Russell, L.M.: Polysacharides, proteins, and phytoplankton fragments: Four chemically distinct types of marine primary organic aerosol classified by single particle spectroscopy. Hindawi Publishing Corporation, Adv. Meteorol., 2010, doi:10.1155/2010/612132, 2010.

Keene, W. C., Pszzenny, A. A. P., Galloway, J. N., and Hawley, M. E.: Sea-salt corrections and interpretations of constituent ratios in marine precipitation, J. Geophys. Res., 91, 6647-6658, 1986.

Keene, W. C., Maring, H., Maben, J. R., Kieber, D. J., Pszenny, A. A. P., Dahl, E. E., Izaguirre, M. A., Davis, A. J., Long, M. S., Zhou, X., Smoydzin, L., and Sander, R.: Chemical and physical characteristics of nascent aerosols produced by bursting bubbles at a model air-sea interface, J. Geophys. Res., 112, D21202, doi:10.1029/2007JD008464, 2007.

Krishnamurti, T. N., Jha, B., Prospero, J., Jayaraman, A., and Ramanathan, V.: Aerosol and pollutant transport and their impact on radiative forcing over the tropical Indian Ocean during the January-February 1996 pre-INDOEX cruise, Tellus B, 50(5), 521-542, 1998.

Kulshrestha, U. C., Jain, M., Mandal, T. R., Gupta, P. K., Sarkar, A. K., and Parashar, D. C.: Measurements of acid rain over Indian Ocean and surface measurements of atmospheric aerosols at New Delhi during INDOEX pre-campaigns, Curr. Sci., 76, 968-972, 1999.

Kulshrestha, U. C., Jain, M., Sekar, R., Vairamani, M., Sarkar, A. K., and Parashar, D. C.: Characteristics and source apportionment of aerosols over Indian Ocean during INDOEX-1999, Curr. Sci. (Suppl.), 80, 180-185, 2001.

Kulshrestha, U. C., Granat, L., Engardt, M., and Rodhe, H.: Review of precipitation chemistry studies in India-a search for regional patterns, Atmos. Environ., 39, 7403-7419, 2005.

Lapointe, B. E.: Phosphorus and nitrogen-luruted photosynthesis and growth of Gracilaria tikvdhlae (Rhodophyceae) in the Florida Keys: an experimental field study, Mar. Biol., 93, 561- 
$568,1987$.

Leck, C. and Bigg, E. K.: A modified aerosolcloudclimate feedback hypothesis, Environ. Chem., 4, 400-403, doi:10.1071/EN07061, 2007.

Leck, C. and Bigg, E. K.: Comparison of sources and nature of the tropical aerosol with the summer high Arctic aerosol, Tellus A and B, 60(1), 118-126, doi:10.1111/j.1600-0889.2007.00315.x, 2008.

Leck, C., Heintzenberg, J., and Engardt, M.: A meridional profile of the chemical composition of submicrometer particles over the East Atlantic Ocean: Regional and hemispheric variabilities, Tellus B, 54, 377-394, 2002.

Mohnen, V., Santroch, J., and Vet, R.: Report of the workshop on precipitation chemistry laboratory techniques, WMO Report no. 102, Hradec Kralove, Czech Republic, 17-21 October, 1994.

Momin, G. A., Ali, K., Rao, P. S. P., Safai, P. D., Chate, D. M., Praveen, P. S., Rodhe, H., and Granat, L.: Study of chemical composition of rainwater at an urban (Pune) and a rural (Singhagad) location in India, J. Geophys. Res., 110. D08302, doi:10.1029/2004jd004789, 2005.

Moody, J. L., Pszenny, A. A. P., Gaudry, A., Keene, W. C., Galloway, J. N., and Polian, G.: Precipitation composition and its variability in the southern Indian Ocean: Amsterdam Island, 1980-1987, J. Geophys. Res., 96, 20769-20786, 1991.

Mouli, P. C., Mohan, S. V., and Reddy, S. J.: Rainwater chemistry at a regional representative urban site: influence of terrestrial sources on ionic composition, Atmos. Environ., 39, 999-1008, 2005.

Norman, M. and Leck, C.: Distribution of marine boundary layer ammonia over the Atlantic and Indian Oceans during the Aerosols99 cruise, J. Geophys. Res., 110, D16302, doi:10.1029/2005JD005866, 2005.

Norman, M., Das, S. N., Pillai, A. G., Granat, L., and Rodhe, H.: Influence of air mass trajectories on the chemical composition of precipitation in India, Atmos. Environ., 35, 4223-4235, 2001.

Norman, M., Leck, C., and Rodhe, H.: Differences across the ITCZ in the chemical characteristics of the Indian Ocean MBL aerosol during INDOEX, Atmos. Chem. Phys., 3, 563-579, doi:10.5194/acp-3-563-2003, 2003.

Ramachandran, S.: Premonsoon shortwave aerosol radiative forcings over the Arabian Sea and tropical Indian Ocean: yearly and monthly mean variabilities, J. Geophys. Res., 110(D7), D07207, doi:10.1029/2004jd005563, 2005.

Ramanathan, V. and Crutzen, P.: New directions: Atmospheric brown clouds, Atmos. Environ., 37(28), 4033-4035, doi:10.1016/S1352-2310(03)00536-3, 2003.

Ramanathan, V., Crutzen, P. J., Lelieveld, J., Mitra, A. P., Althausen, D., Anderson, J., Andreae, M. O., Cantrell, W., Cass, G. R., Chung, C. E., Clarke, A. D., Coakley, J. A., Collins, W. D., Conant, W. C., Dulac, F., Heintzenberg, J., Heymsfield, A. J., Holben, B., Howell, S., Hudson, J., Jayaraman, A., Kiehl, J. T., Krishnamurti, T. N., Lubin, D., McFarquhar, G., Novakov, T., Ogren, J. A., Podgorny, I. A., Prather, K., Priestley, K., Prospero, J. M., Quinn, P. K., Rajeev, K., Rasch, P., Rupert, S., Sadourny, R., Satheesh, S. K., Shaw, G. E., Sheridan, P., and Valero, F. P. J.: Indian Ocean Experiment: an integrated analysis of the climate forcing and effects of the great Indo-Asian haze, J. Geophys. Res., 106(D22), 28371-28398, 2001.
Ramanathan, V., Chung, C., Kim, D., Bettge, T., Buja, L., Kiehl, J., Washington, W. M., Fu, Q., and Sikka, D. R.: Atmospheric brown clouds: Impacts on south Asian climate and hydrological cycle, in: Proceedings of the National Academy of Sciences, USA, 2005.

Ramanathan, V., Li, F., Ramana, M. V., Praveen, P. S., Kim, D., Corrigan, C. E., Nguyen, H., Stone, E. A., Schauer, J. J., Carmichael, G. R., Adhikary, B., and Yoon, S. C.: Atmospheric brown clouds: Hemispherical and regional variations in long- range transport, absorption, and radiative forcing, J. Geophys. Res., 112, D22S2, doi:10.1029/2006JD008124, 2007a.

Ramanathan, V., Ramana, M. V., Roberts, G., Kim, D., Corrigan, C., Chung, C., and Winker, D.: Warming trends in Asia amplified by brown cloud solar absorption, Nature, 448(7153), 575-578, doi:10.1038/nature06019, 2007b.

Rastogi, N. and Sarin, M. M.: Chemistry of Precipitation Events and Inter-Relationship with Ambient Aerosols over a SemiArid Region in Western India, J. Atmos. Chem., 56, 149-163, doi:10.1007/s10874-006-9047-5, 2007.

Salve, P. R., Maurya, A., Wate, S. R., and Devotta, S.: Chemical composition of major ions in rainwater, B. Environ. Contam. Tox., 80(3), 242-246, 2008.

Seto, S., Oohara, M., and Ikeda, Y.: Analysis of precipitation chemistry at a rural site in Hiroshima Prefecture, Japan, Atmos. Environ., 34, 621-628, 2000.

Sievering, H., Cainey, J., Harvey, M., McGregor, J., Nichol, S., and Quinn, P.: Ocean-derived biogenic alkalinity enhances sea-salt sulphate production by ozone oxidation, J. Geophys. Res., 109, D19317, doi:10.1029/2003JD004315, 2004.

Simeonov, V., Kalina, M., Tsakovski, S., and Puxbaum, H.: Multivariate statistical study of simultaneously monitored cloud water, aerosol and rainwater data from different elevation levels in an alpine valley (Achenkirch, Tyrol, Austria), Talanta, 61, 519-528, 2003.

Stone, E. A., Lough, G. C., Schauer, J. J., Praveen, P. S., Corrigan, C. E., and Ramanathan, V.: Understanding the origin of black carbon in the atmospheric brown cloud over the Indian Ocean, J. Geophys. Res., 112, D22S23, doi:10.1029/2006JD008118, 2007.

Tiwari, S., Kulshrestha, U. C., and Padmanabhamurty, B.: Monsoon rain chemistry and source apportionment using receptor modelling in and around National Capital Region (NCR) of Delhi, India, Atmos. Environ., 41, 5595-5604, 2007.

Topcu, S., Incecik, S., and Atimtay, A. T.: Chemical composition of rainwater at EMEP station in Ankara, Turkey, Atmos. Res., 65, 77-92, 2002.

Verver, G. H. L., Sikka, D. R., Lobert, J. M., Stossmeister, G., and Zachariasse, M.: Overview of the meteorological conditions and atmospheric transport processes during INDOEX 1999, J. Geophys. Res., 106(D22), 28399-28413, 2001. 